\title{
Relations of Authority and Submission through Dance during Wedding Festivity
}

Sofia Garifallopoulou

School of Physical Education \& Sport Science/Democritus University of Thrace, Komotini, 69100, Greece

Dafni Anastasia Filippou

Faculty of Law, Strasbourg, France Email: dafnouko1997@gmail.com

Stamatis Chrysis

5th Lyceum of Veria, Greece

Koupani Aikaterini

1st Elementary School of Goumenissa, Greece

\section{Doi:10.5901/mjss.2016.v7n2s1p395}

\begin{abstract}
The purpose of the present study was to investigate and explore the developing relationships based on power/hegemony, inferiority and equality between the newlyweds' families of different ethnic groups during the festivities connected with the wedding ceremony, and particularly with the traditional dancing. Data were collected largely based on the principles of ethnographic method as well as on the use of primary and secondary sources related to fieldwork with the form of participating observation from researchers' point of view. For the analyses of data both the methodological model, proposed by Van Gennep (1960) and Gramcsi's theory (1971) about cultural hegemony, were exploited. With respect to data analyses, it has been established that the groom's parents gain leadership and dominance over the bride's family during the wedding ceremony, and especially during the dancing procedures.
\end{abstract}

Keywords: traditional and modern Greek society, traditional dance, hegemony, marriage

\section{Introduction}

Wedding has always been and still remains a major event in people's life, globally. In addition, wedding is an important ritual passage through which both the man and the woman complete their "adulthood", each one in a different way (Cowan, 1990). Every human is born having in mind to marry and give birth to children (Sergis, 2007). In contrast with the public space where male's presence is above all the others', it is believed that marriage belongs mainly to a female's sphere of thinking as an event which is taking place in residential area, (Michaltsi, Filippou, Lazarou, 2003). As such, wedding ceremony provides a woman the opportunity to have the first place. Moreover, wedding's ritual is a pathway to people's social and physical limits that reproduce the society herself by their association. However, the wedding ceremony is as well one of the most significant occasions which provides opportunities for integration/incorporation and allows the organization of a variety of customary.

Dancing, in both traditional and modern Greek society, constitutes a significant element of social behaviour. The "chorostasi", which on many occasions in the past was the main square and nowadays the scenes of different dance clubs, converts into a theater, where team's structure and organization are transported and all the values and beliefs are reflected (Filippou, 2014; 2015). Every dancing scene is changing into a place where the contradictions which already exist among members are exposed and the conflicts between men and women, rich and poor native and foreign seemed to be considerably lessening (Zografou, 2003). The positions that dancers will get in the circle, which, in a great percentage, are determined by the dance occasion, will depend entirely on gender, age, social and family situation of each dancer (Pitsi \& Filippou, 2014; Filippou, 2015). Dancer's position in circle, the way in which he will dance and express himself and dance's duration are the pretext for discrimination, divisions and rivalries among dancers (Loutzaki, 1992; Zografou, 2003). As we all know, dance is a non-verbal communication form, and for that we put him into practice in "chorostasi" where dancers and spectators are exactly the same, since the viewer is actively involved in the whole dancing procedure. The almost perfect identification between dancers and audiences is accomplished through a common 
aesthetic code that every community has chosen to adopt and which is nothing more than community's dancing identity. Even until today, marriage is a dancing circumstance where people dance in a traditional way, since according to Lamet (1980) the custom, with its wide sociological sense, is the reason that pushes people to dance traditionally at weddings, even today. The same applies to the members of the Greek society and especially for those living in small communities i.e., a village. Generally, during the wedding ceremony which takes place in a Greek village, the participation of newlywed's extended family and relatives, as well as of the inhabitants of their community, is usually universal. This participation has a dual purpose. In the first place, by engagement in the wedding's ritual and festivity procedures, the gests honor the couple by expressing among others feelings of joy, happiness, gratitude etc. Secondly, they exploit the opportunity of having plainly fun.

The aim of the present study was to investigate the developing relationships between the newlyweds' families during the wedding ceremony between a Sarakatsan man and a woman from Asia Minor with a best man from Thessaly. Furthermore, to examine the kinds of social relations, and relations based on power/hegemony, inferiority and equality, which are noticed during the traditional dance that is taking place in the occasion of a marriage among people of different ethnic groups.

\section{Collection of Ethnographic Data}

Data's collection was based largely on the principles of ethnographic method as well as on the use of primary and secondary sources. Primary sources are related to fieldwork with in the form of participating observation from the researchers' point of view (Gefou-Madianou, 1999; Lydaki, 2001), which was based on: a. semi-structural or completely unstructured interview (Filias, 1993), in other words on data's highly accumulation by focusing on informers' testimonies, whose memory is proved to be perfectly strong when it has to do with experiential situations (Thompson, 2002) and b. on wedding feast's observation and recording.

Alongside the primary sources, secondary sources were studied as well. Data's collection from secondary sources was based on archival ethnographic research (Gefou-Madianou, 1999), which contributed to utilize all the necessary and useful information for research's needs.

\section{The Rites of Passage and Theory of Cultural Hegemony}

For data's analysis are being exploited both the methodological model proposed by Van Gennep (1960) and Gramcsi's theory (1971) about cultural hegemony. After a deep studying of French traditional culture, Van Gennep's (1960) model that all traditions, including marriage as well, show up a triple structure. This model consisted of: a. The preliminal rites, separation's phase, which are designed in order to cut off individual from its previous situation $b$. The liminal (or threshold) rites, liminality's phase, during which one has left one place or state but has not yet entered or joined the next and c. The rites of incorporations, incorporation's/integration's phase, which aimed to integrate each person into his/her new social situation.

According to Sergis (2007), in an imaginary level, marriage would have surely been a "war event", if we take in mind that between the newlyweds' families there is an unsung competition about which family will keep on doing all the established customs and on the other hand about which one will do that more richly in a way that she will finally get round to dominate the other one. Gramcsi (1971) called that domination "hegemony" and the ascendant "hegemon/governor". But the word "hegemon" has a double meaning. On the one hand it's meaning the person who is managing to control and limit people's behaviour and on the other hand the one who guides and directs all others. A good leader is the one who combines these two concepts without using violent methods of enforcement.

According to Gramcsi (1971) hegemony/leadership is the dominance which is achieved more by acquiescence rather than by violent behaviour from the one side over the other. It is accomplished through multifarious channels on which society's institutions are based to form their cognitive and psychological structures, by which people perceive and evaluate the problematic social reality. In other words, a group of people or a social class could have been dominated to another group or class by using every day practices and all the common beliefs of these groups, such as their culture, since according to Kapsomenos (2010) the culture represent the total perception of each society about human, nature and world in general. So, it is the system above all the others which is including and prioritising all expressions of material and spiritual life of peoples. This enforcement is carried out by sovereignty's acceptance from each society and through her assimilation in a violent way or not, as it is mentioned above.

Moreover, Gramcsi attributes (1971) this acceptance and consensus to the power of consciousness and ideology and he believes that the system's real power there is not in the ruling class's violence or in the state's restrictive power, 
but in the acceptance of a "worldview" which belongs to dominants, by all the incipient. Ruling class's philosophy goes through a whole web of complicated popularizations, exposed as "common sense": this is majority's philosophy who accepts morality, customs and community's institutionalized behaviour (Campbell, 1964).

This study's interest is gathered in marriage's third phase that i.e. of integration, which includes the wedding table set out on newlyweds' relatives and friends. The wedding table's presentation is the most important of all the other wedding customs since at that time some of the most important wedding's messages are being relayed.

\section{Results - Discussion}

The time is ten on a Saturday night. The entire guest, All the guests, almost 600 people from both groom's and bride's sides, have already taken their seats in the center, which is customary in wedding parties. It is more than obvious that groom's guests outnumber those of the bride. There are also representatives from Panhellenic Federation of Sarakatsanoi as the groom's guests. In the restaurant's center, in front of dance floor, the bridal table has been placed, where the newlyweds' and best man's relatives have already taken their seats, waiting for the newlyweds to arrive. The groom's guests are sitting at tables on the right side of the orchestra and the bride's from on the left. Background music, of the newlywed's choice, is consisting solely of Sarakatsans' songs.

Shortly afterwards the background music changes and the sound of a foreign song is heard and all the guests started to applaud. Then the newlyweds, accompanied by the best man move to the centre of the dance floor where a tripod with the wedding cake has set up. During wedding cake's cutting ceremony the same foreign music can be heard. The couple's first dance is then performed with the song "Strangers in the Night». There is no one in the dance floor, yet, rather than the newlywed couple. After its first dance, the couple is going to bridal table, next to their relatives.

The orchestra and singers then sit down and after wishing the newlyweds all the best the orchestra begins to play the song "Orea pou einai I nifi mas/How beautiful is our bride" during which only people coming from bridal table are dancing. Dancers' arrangement is the following: bride, groom and best man are holding the first three places. They are followed by groom's parents, bride's parents and brother. After they have done some circles, groom's father moved apart the circle and he's now coming close to the bride. He's draping her dress with money. The same thing is immediately being done by his wife and bride's parents, brother and guests in the end. That is called as "bride's treat". While the "treat" is continuing, the song that is heard is "The house that we're coming today". The bride is still in the first place of the circle while all the rest are remaining at their positions. All the guests in order get up and "treat" the bride for a long time.

It is now groom's turn to dance in the first place. He has chosen to dance "Tsamikos" with the song "The youth age". Only his father donates him money, no one else. He's dancing, with the same relatives. A short time after, a group with a flag (Flamburas ${ }^{1}$ ) in their hand enter the dance floor. They are groom's friends (bratimia) together with members from Panhellenic Federation of Sarakatsanoi. They give the groom the Flamburo and he continues to dance while holding it up. During groom's dance, the group is clapping in circle's centre.

It is then the turn of newlyweds' parents to dance with their children. So, the groom's mother starts the bride dancing with "Syrtos" and her boy with "Tsamikos". After that, his father is dancing a Sarakatsan's dance with the bride and "Katsa", another Sarakatsan dance, with the groom. The bride's parents are dancing with both the newlyweds "Syrtos" from Asia Minor - a dance from their cultural group. However, her brother is dancing "Syrtos with three steps", a dance which belongs to Thessaly's and Epirus' dancing repertoire.

Finally there is a dance for newlyweds' relatives. The strange thing is that they are dancing separately. In other words, when groom's relatives are dancing, no one from the bride's side is dancing. However, when is the turn of bride's relatives to dance, some of the groom's family join in dancing with them. The groom's relatives' repertoire consisted only of Sarakatsans' dances, whereas the bride's relatives' repertoire is a mix of Asia Minor's and Islands' "Syrtos", "Beratia" and a Thessalian's song named "Bikan ta gidia sto mandri".

After bride's relatives have finished their dance, it is the turn of official guests to dance. So, the singer invites groom's closed friends to dance. These are members of Panhellenic Federation of Sarakatsanoi, and as it was expected, their songs and dances are from Sarakatsan's repertoire and in particular dances such as "Tsamikos", "Katsa" and "Syrtos with three steps".

That marks the end of official bridal celebration, since according to groom's father's words "Beyond doubt, the real feast had finished when our relatives and guests stopped dancing. After that, everyone else made his choice about several dances".

${ }^{1}$ Flamburas is the flag of the wedding and consists of the pole and flag. The pole is made of wood, usually cornel, and symbolizes the robust of bride and groom and their descendants. In cross nailed three apples or pomegranates which symbolized love and fertility. 
The bride danced "Zagorisio", a dance from her husband's cultural group. Apart from this, she danced "Zeibekiko" alongside with her husband and her mother.

All in all, we can see that during the whole night, Sarakatsans have been dancing much more time than the relatives from bride's family. The groom's family and their guests have been dancing for one hour and twenty minutes and bride's only forty minutes.

Mr. K., the groom's father, was clear and assertive: "As the groom's parents, we have helped the couple with songs' choice. We have the right to do so and not the other family, because we are Sarakatsans. We don't look down on the others but we believe that even the song that our bride has danced to wasn't of her side, it was the dance that all the brides used to dance with great honor".

From what Mr. K. has said, it's obvious that groom's family wanted to have the whole feast under their control and to organize the wedding according to their own desires, without taking into account bride's family's wishes. As well as that, they didn't even ask the other family about the wedding's dancing repertoire neither did they have a conversation about them with them about the orchestra or the singer, but they ordered the dances without consulting them. Even though the bride's family wasn't consulted, none of them behaved negatively, because all the songs were similar and didn't detract from the celebrations. When it comes to the bride's parents, not only did they not react adversely to dances' repertoire, but they accepted as it as it was organized by the other family. Perhaps, they did so because of the prevailing view that "groom is defining the marriage details", which exist in traditional societies. That view seems to agree with Williams' one (1977:112): "The already lived hegemony is always a process. There is not a system of structure, only when it comes to analytical purposes. It is a vibrant group of experiences, relationships, and activities, with specific and changing pressures and limits. Williams' view is confirmed by what groom's parents keep on saying below: "songs like those were played because bride's relatives aren't only from Asia Minor but from Thessaly (Karagounides) and other cultural groups as well. For that reason the repertoire was organized in a way that everyone will be satisfied". In this point it is obviously noticed an alluring proposition and an acquiescence, that "we were thinking about bride's relatives, who aren't from Asia Minor and due to that we've added songs from Thessaly to wedding's repertoire". This is an attempt in order to ensure the consensus of bride's parents about the quality of their actions.

Groom's family's hegemony it is also shown by non-verbal elements of wedding's ceremony. On average, groom's guests have occupied more tables and they have danced for a longer time than the bride's guests. The groom's family said: "we had a lot more guests than the bride had, but we didn't invite them all because we wouldn't have been comfortable in the centre we've booked". For Sarakatsans, it's very important that the majority of their relatives to be involved in such special family occasions, since they believe that relational ties are an inseparable component of their society (Velioti - Georgopoulos, 2004). The "natural affinity" is completed by the relationship which is shaped through the whole marriage's testimony (Nitsiakos, 1991).

The wedding party is starting with groom's closest relatives, including best man, one of the most important people in the whole ceremony, and his family as well. We all agree that the best man is a respected person, since without him it wouldn't be possible for the whole marriage's testimony to be carried out normally. Therefore, his honoured position should be recognized by everyone during the wedding feast. Consequently, he will dance as a prime dancer with newlyweds and their families (Velioti - Georgopoulos, 1996).

In small communities, it is of great importance who will dance in first position of the circle, as it is believed that the person who will do so is capable of reinforcing his position in local society (Velioti-Georgopoulos, 1987; Filippou et all, 2006 Additionally, those who can dance in this position are people who, from the one hand, have a good knowledge about dance's kinetic part and perform it properly and on the other hand those who they are familiar with the rules and the types of the whole dance's performance.

Another element is the music that was played in the club whilst waiting for the newlyweds to arrive. The guests' arrival time had been planned for nine o'clock in the evening, but the couple arrived an hour later. During that expectance, only Sarakatsans' music and song were heard. The argument that they put forward for this was that: "all the traditional songs are Greek. The difference between them makes the way that they are sang and danced by everyone. When it comes to Sarakatsans' song, these were played for us, to be next to our tradition and not go away from her". Sarakatsans' one-sided tradition "for us to be close to tradition..." without having in mind bride's family's tradition and groom's guests' numerical majority are used as strong arguments from his side in order to convince the others for their right and also to take their permission for song's type and duration in the feast. And if they fail to obtain their consent by behaving in a good way, there is also the coercion and the hegemony: "the feast has been organized like this because L. was our only child and wanted to gain a life experience through that event". And, when we have raised our objection that bride's family would like to make the marriage according to their proper culture, Mr. K. said that "they can organize their son's marriage just like they want to". 
According Alexakis (1990), "Flamburo"/flag was absolutely necessary for a wedding. In fact, its construction's beginning was at the same time the official start of weddings ceremonies. It was unthinkable for the wedding of our research to not have a "Flamburo". In groom's first dance as a prime dancer, his close friends (bratimia) give him the "Flamburo" and he started dancing with it in his hands by making, in that way, fairly obvious their cultural identity to almost anyone and especially to bride's relatives and guests. Without doubt, this became even more evident through the members of Panhellenic Federation of Sarakatsanoi. They have come from different places all over the Greece, such as Komotini, Thessaloniki and Athens. As their table has been placed near couple's table, they've became barely perceptible by everyone. Added to that, when they had been invited by the singer to dance, he previously announced that the following dances would be only for them. For that reason during Sarakatsans' dances, only the groom and his guests were on the dance floor and none else.

The fact that bride's parents have danced two dances from Asia Minor and their own cultural group doesn't mean anything. A good leader knows very well how to subjugate his opposites in order to have no reaction from them. After all, as it was mentioned above, the groom's guests have danced far more times than the bride's guests have.

In conclusion, it is obvious that groom's parents, being wedding feast's main organizers, they propounded and imposed their cultural identity during the wedding's ceremony by using both forms of cultural hegemony i.e., the "convincing method" and the "violent method", in order to gain leadership and dominance over the bride's family.

\section{References}

Alexakis, Eleftherios 1990. The flag in marriage: an ethnological study. Athens.

Campbell, John K. (1964). Honour, Family and Patronage: A Study of Institutions and Moral Values in a Greek Mountain Community. Clarendon Press, Oxford.

Cowan Jane 1999. Dance and the Body Politic in Northern Greece. Princeton, N.J.: Princeton University Press.

Filias, Vasilios 1993. Introduction to methodology and techniques of social research.

Athens: Gutenberg.

Filippou, Filippos 2014. The role of the kinetic motif in determining the form and time of dance through the dance "Tis Marias". Journal of Physical Education and Sport, 14(1), Art 18, 115 - 119.

Filippou, Filippos 2015. The first woman's dancer improvisation in the area of Roumlouki (Alexandria) through the dance "Tis Marias". Ethnologia, 6(b):1-24. [Online] Available: http://www.societyforethnology.gr/site.pdf/The_first_woman's_dancer_improvisation.pdf (April, 2015).

Filippou Filippos, Serbezis Vasilios, Harahoussou Yvonne, Kabitsis Christos, Koleta Maria, Varsami Dimitra, Varsami Helene, Davoras Demos 2006. The folk dance as theatrical performance and the Training of Dance Teachers. Arts and Humanities in Higher Education, Vol 5(1) 51-63.

Gramcsi, Antonio 1971. Selections from the Prison Notebooks. London: Lawrence \& Wishart.

Gefou - Madianou, Dimitra 1999. Civilization and Ethnography: from ethnographic Realism to Cultural Criticism. Athens: Greek Letters.

Kapsomenos, Eratosthenes 2010. Relationships between politics and culture. Antifonitis. 1/2/2010: 10.

Lamet, E 1990. Les danses folkloriques, gestes rituelles. Documents d'Ethnologie Régionale, 11, 21-48.

Loutzaki, Irene 1983-1985. Marriage as a Dance Event. The case of the refugee from Eastern Rumelia at Micro Monastiri, Macedonia. Ethnographika.vol 4-5. Nafplion: Peloponnesian Folklore Foundation. 142-176.

Loutzaki, Irene 1992. In favour of anthropology of dance. Ethnographika. Nafplion. Peloponnesian Folklore Foundation: 11-25.

Lydaki, Anna 2001. Qualitative methods in social research. Athens. Kastaniotis.

Michaltsi Maria, Filippou Filippos, Lazarou Anna 2003. Social Development and Folk Dance in Flambouro of Florina. PEPFA (23/09/0323/10/03. www.pepfa.gr/06-periodiko.

Nitsiakos, Vasilios 1991. Traditional social structures. Athens. Odysseas.

Pitsi Athina, Filippou Filippos 2014. Dancing and music in symbiotic groups: the example of the Vlahs-Armani of Seli Imathias-Greece. Journal of Physical Education and Sport, 14(2), $205-210$.

Sergis, Manolis 2007. Rites of Passage at Pontus: Birth, marriage and Death. Athens: Herodotus.

Thompson, Paul 2002. The Voice of the Past: Oral History.(in Greek). Athens. Plethron.

Van Gennep, Arnold 1960. The rites of passage. Met. Vizedom, MB, Cafee, GL. Chicago: The University of Chicago Press (1st published in France 1908).

Velioti-Georgopoulos, Maria 1987. Le parrainage, l'adoption et la fraternisation dans un village aryanité du Péloponnèse. Etudes et Documents Balkaniques et Méditerranées. (13) 69-76.

Velioti-Georgopoulos, Maria 1996. L'aspect dynamique de la Grèce rural. Changement économique, identité culturelle et liens de parenté à Didima, village du Péloponnèse. Thèse de doctorat non publiée, Ecole des Hautes Etudes en Sciences Sociales, Paris.

Velioti - Georgopoulos, Maria 2004. Dance and Kindred or the "Turn in Dance" During the Wedding Feast. Arxaiologia kai Texnes (92). Athens. 17-22.

Williams, Raymond 1977. Marxism and Literature. London: Oxford University Press.

Zografou, Magdalini 2003. The dance in Greek tradition. Athens: Art Work. 